\title{
SISTEM KASTA \\ Kajian Teologi Sosial Terhadap Praktek Pelaksanaan Kasta di Kepulauan Kei Kabupaten Maluku Tenggara
}

\section{Marthinus Ngabalin}

\begin{abstract}
The system of social stratification or Caste is a part of social life reality in the Kei Islands. Through system of Caste, the community were grouped into social classes. However, if traced in more depth, so in practice the implementation of the Scheduled Caste has human values that are the base of culture in community.
\end{abstract}

Keywords: Caste, Social stratification and humanity

\begin{abstract}
Abstrak
Sistem pelapisan sosial atau Kasta adalah bagian dari realitas hidup bermasyarakat di Kepulauan Kei. Melalui sistem Kasta masyarakat di kelompokkan dalam kelas-kelas sosial. Namun jika ditilik secara lebih mendalam, maka di dalam praktek pelaksanaan Kasta memiliki nilai-nilai kemanusiaan yang basisnya adalah kebudayaan di dalam masyarakat.
\end{abstract}

Kata Kunci: Kasta, Pelapisan Sosial dan kemanusiaan

\section{A. PENDAHULUAN}

Perbedaan merupakan sebuah konsep yang patut ditelusuri dalam kehidupan bermasyarakat. Karena dengan konsep tersebut, seringkali terdapat klasifikasi dalam kehidupan bersama yaitu: orang sederajat, orang yang lebih tinggi derajatnya dari orang yang lebih rendah derajatnya. Secara tidak langsung perilaku tersebut menciptakan pelapisan sosial/kelas. Seorang Sosiolog terkemuka Pitirim A Sorokinmengatakan bahwa sistem pelapisan merupakan ciri yang tetap dan umum dalam setiap masyarakat yang hidup teratur. Selain sebagai suatu realita, sistem pelapisan sosial dalam masyarakat juga adalah sesuatu yang bersifat universal, dalam arti ada dalam setiap masyarakat dan ada sejak manusia mengenal adanya kehidupan bersama di dalam suatu organisasi sosial. 
Dengan demikian, adanya pelapisan sosial dalam setiap masyarakat karena masyarakat senantiasa mempunyai penghargaan tertentu kepada hal-hal tertentu dalam masyarakat yang bersangkutan. Misalnya: keturunan, pendidikan dan pekerjaan. Oleh sebab itu, dalam konteks kehidupan bersama seringkali juga terdapat kesenjangan ditengah-tengah komunitas kehidupan bersama. Sebagaimana juga dikatakan Max Weberbahwa masyarakat dibagi ke dalam lapisan-lapisan tidak hanya berdasarkan ekonomi saja, tetapi juga berdasarkan hak istimewa, besarnya kehormatan yang diberikan masyarakat, dan khususnya kuasa yang dimiliki. ${ }^{\mathrm{i}}$

Bertolak dari uraian di atas, maka jika ditelusuri salah satu konsep budaya dari masyarakat kepulauan Kei, yang akan menjadi fokus kajian ini adalah: Sistem kasta, yang

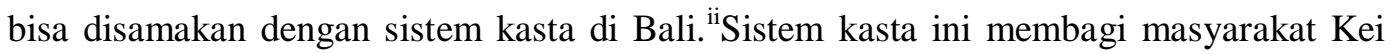
dalam tiga bagian yakni: kasta atas,[disebut: Mel-mel], kasta menengah [disebut: Renren] dan kasta rendah [disebut: Iri-iri] ${ }^{\text {iii }}$ Menurut Susan Mackinnon [1991: 144]:

Corak hierarki masyarakat Kei seperti ini menunjuk pada pola a-simetrik, suatu pola bertingkat di mana masyarakat tersusun mengikuti peran-peran tertentu pada setiap kelompok. Peran-peran dan kedudukan itu sekaligus menjadi corak status mereka yang baku, dan tidak ada akses "naik kelas" kepada kelompok lainnya.

Untuk memahaminya, maka sistem kasta di Kei akan dikaji dari segi etimologis [pengertiannya],letak geografis kepulauan Kei, segi historis: kasta di kepulauan Kei,dampak kasta bagi masyarakat kepulauan Kei, dan diakhiri dengan sebuah refleksi teologi sosial mengenai bagaimana pandangan masyarakat Kei tentang praktek pelaksanaan sistem kasta di tengah-tengah budaya mereka.

\section{B. PENGERTIAN KASTA}

Istilah kasta berasal dari bahasa Latin: castus yang berarti utama, suci, tak bernoda, murni, sopan, terhormat. Kemudian kata castus di dalam bahasa Portugis berubah menjadi casta yang berarti keturunan, ras. Kemungkinan pengertian casta menurut bahasa Portugis ini kemudian dipakai oleh orang Barat untuk membedakan atau menggolongkan kelompok-kelompok sosial yang ada di India. ${ }^{\text {iv }}$ 
Menurut Dahrendorf, istilah kelas pertama kali diperkenalkan oleh penguasa Romawi kuno, dan sepanjang sejarahnya istilah ini telah mengalami pergeseran arti. Penguasa Romawi kuno menggunakan istilah itu dalam konteks penggolongan terhadap para pembayar pajak. Mereka membagi masyarakat Romawi menjadi dua golongan yaitu: assidui atau golongan kaya dan proletariat atau golongan miskin. ${ }^{\mathrm{v}}$

Ini berarti istilah kasta/kelas berada dan berkembang searah dengan perkembangan zaman dan digunakan sesuai dengan konteks perkembangan masyarakat itu sendiri. Misalnya, dalam sejarah perkembangan para sosiolog klasik istilah ini juga di gunakan pada abad ke 19, oleh Karl Marx [1818-1883], tokoh sosiolog Jerman yang menggunakan istilah ini bagi masyarakatnya yang disebut dengan golongan borjuis[golongan kaya] dan proletar [ golongan miskin] konsep ini muncul akibat perkembangan industri pada zaman itu. ${ }^{\mathrm{vi}}$ Kelas, menurut Marx, menunjuk kepada:

Himpunan orang-orang yang memperagakan fungsi-fungsi yang sama dalam organisasi produksi. Kelas-kelas dalam masyarakat dibedakan antara satu dengan yang lainnya berdasarkan perbedaan posisi dalam penguasaan alat-alat produksi. ${ }^{\text {vii }}$

Perbedaan secara tegas antara kelas dan status antara lain dikemukakan juga oleh Max Weber [1864-1920] dengan pengajuan konsepsi tentang:

Kelas, status dan kekuasaan. Ketiga istilah itu menunjukkan kepada tiga dimensi tatanan sosial suatu masyarakat. Dalam hal ini kelas merupakan kategori dari manusia yang mempunyai kesamaan dalam komponan kausal spesifik dari kesempatan hidup sejauh hal ini berhubungan dengan kepentingan ekonomi dalam kepemilikan barang dan pendapatan dalam barang dagangan dan pasar tenaga kerja. Status merupakan perwujudan stratifikasi sosial berkenaan dengan prinsip-prinsip yang dianut oleh masyarakat yang bersangkutan dalam mengkonsumsi harta benda berdasarkan posisi dalam proses produksi. Kekuasaan merupakan perkumpulan sosial yang berorientasi pada penggunaan kekuasaan sosial yang berpengaruh kepada masyarakat. ${ }^{\text {vii }}$ 
Konsep Weber tentang kelas merupakan perluasan konsep kelas yang diajukan oleh Marx. Terutama ketika melihat faktor ekonomi sebagai salah satu dimensi yang dapat menentukan kedudukan relativ seseorang diantara yang lain. Konsep Webertentang kelas ini masih ada kemungkinan untuk terjadi peningkatan kelas hal ini disebabkan karena, jika dalam masyarakat bekerja keras, hemat dan sungguh-sungguh maka akan terjadi perpindahan kelas. Ini berarti konsep kelas itu sendiri tidak bersifat statis dan tertutup namun dia bisa berubah tergantung pada masyarakat itu sendiri.

Dengan demikian, bagi Amalados, sistem kasta adalah:

Suatu cara mengorganisasikan masyarakat. Sebuah kasta merupakan sebuah kelompok endogam. Orang-orang yang termasuk suatu kasta tidak mengadakan ikatan perkawinan di luar kasta mereka. Dengan demikian sebuah kasta bersifat turun temurun orang-orang dilahirkan dalam suatu kasta. Sebuah kasta bercirikhaskan suatu pekerjaan khusus: bertani, menjadi prajurit, berdagang, dan sebagainya. Masyarakat berupa penataan berbagai kasta secara hirarkis.

Oleh sebab itu, berbagai teori yang telah dikemukakan di atas, digunakan sebagai pisau analisis dalam menggambarkan sistem kasta yang dianut oleh masyarakat kepulaun Kei.

\section{LETAK GEOGRAFIS KEPULAUAN KEI}

Kepulauan Kei terletak di sebelah Tenggara Maluku antara 5 ' -6 '5'Lintang Selatan dan 131'50' - 135'51' Bujur Timur. Posisiitu menunjuk bahwa kepulauan ini terletak di wilayah pesisir pantai yang mengarah ke laut. Ini potensial bagi masuknya berbagai pengaruh budaya baru dari luar, sebagai akibat dari kontak sosial dengan wilayah-wilayah itu. Kepulauan ini, terdiri dari 112 pulau yang dapat dibagi menjadi dua kelompok besar yaitu kepulauan Kei Besar dan kepulauan Kei Kecil serta tiga kelompok kepulauan kecil[Kur, Tayando, dan Tanimbar]. Luas wilayah 10.374 KM. Serta jumlah penduduk Kepulauan Kei: 193.790 Jiwa. ${ }^{\text {ix }}$ 
Kepulaun Kei termasuk daerah tropis karena terletak di sekitar garis khatulistiwa. Iklimnya dikuasai oleh angin musim, yakni angin yang bertiup pulang balik setiap setengah tahun dalam arah yang berlawanan. Dalam musim Timur [April - Oktober] angin bertiup dari arah Tenggara [Benua Australia] ke arah Barat Laut [Asia Tengah]. Selama bulan-bulan ini kepulaun Kei mengalami musim kering atau musim kemarau, sedangkan dalam setengah tahun berikutnya [Nopember - Maret] angin bertiup dari arah Barat di mana kepulaaun Kei mengalami musim hujan.

Secara umum, kegiatan pertanian di kepulauan Kei dilakukan dengan perladangan daur ulang. Memang di samping perladangan, ada juga yang mencari nafkah melalui nelayan, pegawai negeri sipil, wiraswasta, dll.Sehubungan dengan hal itu, dapat dikatakan bahwa potensi kelautan merupakan andalan dalam pemberdayaan ekonomi kepulauan ini. Dalam hal bahasa, selain berbahasa Indonesia, seluruh kepulauan Keimasih berbahasa daerah untuk urusan seharihari.

\section{SEGI HISTORIS: KASTA DI KEPULAUAN KEI}

Dari tradisi lisan serta dokumen sejarah masyarakat setempat diceritakan bahwa sewaktu perluasan kerajaan Majapahit diwilayah nusantara sampai di kepulauan Kei, maka sistem kasta dibawah masuk kedalam masyarakat setempat, bukti sejarah ini terlihat dimana, dengan dicetuskannya hukum Larvul Ngabal yang merupakan hukum adat setempat yang dianut sampai saat ini.

Selain itu, menurut Ohoitimur, dijelaskan bahwa kastaMel-mel = kelas bangsawan, dan Ren-ren = kelas menengah. Memiliki dua filosofi yang dapatmempersatukan keterlibatan kedua kasta ini dalam suatu pekerjaan, yaitu: ${ }^{\mathrm{x}}$

Pertama, kesil kerbau bo, tes tatotnam hoar yarut, artinya kalau ada musyawarah dan kerjasama antara Mel-mel dan Ren-ren, tentu suatu pekerjaan akan terselesaikan.

Kedua, Mel-mel ni sus, intub fo ren-ren ni sus, Ren-ren ni sus, intub fo Mel-mel ni sus. Artinya: kesusahan Mel-mel adalah juga bagian dari kesusahan Ren-ren, sebaliknya kesusahan Ren-ren adalah juga bagian dari kesusahanMel-mel. Hal itu puladiungkapkan dalam versi lain, yang memiliki pengertian yang sama dengan 
filosofi kedua, yaitu: Yaan ni sus, intub fo Warin ni sus, Warin ni sus, intub fo Yaan ni sus. Artinya: kakak [Ren-ren] punya kesusahan, juga menjadi kesusahan adik [Mel-mel]. Sebaliknya, adik [Mel-mel] punya kesusahan, juga menjadi kesusahan kakaknya [Ren-ren].

Kedua filosofi yang menyatukan dan pemersatukan kedua kasta itu, ternyata memiliki latar belakang historis tersendiri. Dikisahkan, bahwa ketika para pendatang memasuki daerah ini, sudah ada "penduduk asli" xi Mereka disebut sebagai tuan tanah atau tuan tan dan sebagai kakak, sedangkan penduduk pendatang disebut adik. Ketika perjumpaan antara kedua kelompok masyarakat itu berlangsung, penduduk pendatang memperlihatkan kepintaran mereka dalam hal bicara, mengatur, memimpin dan memiliki sikap hidup sopan-santun atau tahu adat, yang jauh melebihi "penduduk asli" xii Berdasarkan kecakapan dan sikap hidup yang beradab itu, "penduduk asli" memberikan kuasa kepada penduduk pendatang untuk mengatur kehidupan mereka secara bersamasama. Kakak, selanjutnya disebut Ren-ren, sedangkan adik disebutMel-mel.

Menurut Ch. Labetubun, ada dua narasi yang menunjukkan bahwa penduduk pendatang memiliki tingkat kecerdasan, pengetahuan dan kesopanan yang lebih dari "penduduk asli", yakni:

Pertama, pada suatu ketika dua orang saudara: kakak dan adik pergi ke hutan untuk memotong bambu. Setelah bambu dipotong, kakak langsung memikul bambu tanpa mengambil tali untuk mengikatnya, sehingga dalam perjalanan pulang, ada bambu yang jatuh. Oleh sebab itu, ketika tiba di desa, bambunya kurang dari yang seharusnya dipikul. Sedangkan, adiknya setelah memotong bambu, ia mengambill tali dan mengikatnya, sehingga secara utuh, bambubambu tersebut dapat dipikul ke desa. Berdasarkan peristiwa ini, "penduduk asli” [kakak] disebut Ren-ren karena kurang cerdas, sedangkan penduduk pendatang [adik] disebut $\mathrm{Mel}$-mel karena kecerdasan yang dimilikinya.

Kedua, pada suatu ketika dua orang saudara itu kembali melakukan suatu perjalanan yang jauh. Ketika mereka hendak melewati suatu desa, ada satu keluarga yang memanggil mereka berdua untuk singgah istirahat sebentar karena mereka melihat kedua orang saudara itu sudah sangat capai. Dua orang saudara ini, kemudian memenuhi undangan tersebut. Mereka beristirahat di teras rumah itu. Selanjutnya, tuan rumah menyediakan ala 
kadar seadanya untuk menghilangkan rasa haus dan mengundang mereka berdua untuk masuk menikmati hidangan itu di ruang tamu. Ternyata yang masuk untuk memenuhi undangan tersebut adalah adik, sementara kakaknya karena merasa kepanasan, tidak mau masuk untuk menikmati hidangan itu. Dari cerita ini, ternyata adik tahu adat dan kakaknya tidak tahu adat [sopan santun]. ${ }^{\text {xii }}$

Sang adik [mel-mel] berdasarkan kelebihan tersebut, dipercayakan untuk memimpin, berbicara di depan umum, mengatur dan memegang pucuk kepemimpinan dalam struktur masyarakat desa, bahkan sampai pada sistem pemerintahan di daerah tersebut. Fenomena tersebut masih berlangsung hingga kini, sehingga hampir tidak ada lagi ruang dan peluang bagikasta Ren-ren dan Iri-iri untuk menjadi pucuk pemimpin, walaupun mereka juga punya kemampuan untuk itu.

Boleh dikatakan bahwa, hal ini telah menimbulkan sikap diskriminatif dan kecemburuan sosial di kalangan masyarakat, terutama dari kasta ren-ren dan iri$i r i^{x i v}$ terhadap $\mathrm{Mel}$-mel,akan tetapi hal ini telah mentradisi dan diterima sebagai bagian dari realitas eksistensi bermasyarakat di Kei. Sikap diskriminasi ini juga dapat menimbulkan ketidakpuasan, tetapi sejauh ini belum mencuat ke permukaan. Hal itu berarti bahwa masyarakat Kei masih "tahu diri". Artinya, mereka mengetahui posisi dan peranan masing-masing. Walaupun begitu, latar belakang sosio-historis tersebut memperlihatkan bahwa Mel-mel dan Ren-ren adalah adik-kakak, orang bersaudara. Sebagai adik-kakak, orang bersaudara, mereka terpanggil untuk bekerja secara bersama-sama dalam semangat tolong menolong. ${ }^{\mathrm{xv}}$

\section{E. DAMPAK KASTA BAGI MASYARAKAT KEPULAUAN KEI}

Dalam prakteknya, pemberlakuan kasta di Kei nampak jelas terlihat dalam sistem pembagian pola pemukiman penduduk [segregasi] yang dibagi berdasarkan kasta, di mana kelas atas[mel-mel] menempati bagian depan kampung, kelas menengah[ren-ren] menempati bagian tengah kampung serta kelas bawah[iri-iri] menempati bagian belakang kampung. Selain itu, konsep ini juga berpengaruh dalam kehidupan sehari-hari, misalnya dalam kerja-kerja sosial dimana yang bertugas untuk membersihkan lingkungan desa adalah kasta bawah 
[iri-iri]. Hal ini bertolak dari sistem pengambilan keputusan dalam masyarakat, di mana suara kasta atas[mel-mel] lebih didengarkan dibandingkan dengan suara dari kasta bawah.

Dengan demikian, sangat diperhatikan tatakrama kasta. Tidak boleh terjadi percampuran kasta, dalam artian kasta atas[mel-mel] dan menengah [ren-ren] tidak boleh bercampur dengan kasta di bawahnya[iri-iri]. Hal ini terbukti dalam pergaulan sehari-hari, Misalnya jika seorang kasta bawah[iri-iri] ingin menghadap Raja,maka ia harus merangkak kira-kira sejauh 10 meter dari luar rumah tuannya sebelum menemui raja atau para pembesarnya.

Selain itu, dalam hubungan perkawinan akibat berlakunya sistem kasta, terutama pada kasta atas [mel-mel] menginginkan adanya perkawinan endogami kasta, dengan maksud agar anggota keluarganya kawin dengan orang-orang sekasta. Apabila salah seorang pria/wanita dari salah seorang keluarganya kawin di luar kastanya dengan seorang pria/ wanita dari kasta yang lebih rendah [iri-iri], maka mereka akan dikucilkan dan dikeluarkan dari keluarganya. ${ }^{\text {xvi }} \mathrm{Hal}$ ini seringkali mengakibatkan pasangan yang telah terlanjur mencintai mereka lebih cenderung untuk melarikan diri ke luar kepulauan Kei.

Dampak lain dari praktek kasta ini adalah, jika seorang dari kasta bawah[iri-iri] memiliki jabatan dan gelar pendidikan yang sangat tinggi namun jika ia kembali ke kampung halamannya, maka ia harus tunduk serta patuh terhadap segala adat istiadat yang berlaku ditengah-tengah kampung halamannya. ${ }^{\text {xvii }}$

Oleh sebab itu, dalam pengalaman kehidupan bergereja jika penempatan seorang Pendeta yang berasal dari kepulauan Kei di kepulauan Kei masih melihat latar belakang kastanya. Hal ini disebabkan karena, sosok Pendeta tersebut hadir dan diterima oleh warga masyarakatnya untuk melaksanakan tugas dan tanggungjawabnya hanya untuk memberitakan firman, namun jika ia telah selesai berkhotbah maka ia harus patuh dan taat terhadap hukum adat yang berlangsung di tengah-tengah masyarakatnya. Dalam kehidupan bergereja posisi tempat duduk dalam gereja pun dibagi-bagi. Misalnya, kasta atas [mel-mel] menempati kursi bagian depan, kasta menengah [ren-ren] menempati kursi bagian tengah dan kasta 
bawah [iri-iri] menempati kursi bagian belakang. Dengan demikian, dalam realitas yang terjadi terus ada saja diskriminasi-diskriminasi sosial di tengahtengah kehidupan bermasyarakat dan bergereja.

Yang unik, dalam stratifikasi sosial masyarakat Kei justrukasta bawah [iriiri], tidak pernah memberontak dari pengaruh kasta atas [mel-mel] dan kasta menengah [ren-ren]. Mereka sering berbeda pandangan namun selalu saja ada keputusan yang keluar sebagai hasil kesepakatan yang dipimpin oleh kasta atas [mel-mel]. Uniknya, kasta bawah [iri-iri] sudah melihat sistem ini sebagai sesuatu yang tidak bisa dilanggar atau yang ada sejak dulu dan cenderung tidak memberontak.

\section{F. REFLEKSI TEOLOGI SOSIAL}

Refleksi Teologis - sosial dimulai dengan kenyataan sosial atau situasi yang dialami bersama.Untuk menangkap situasi yang dialami bersama, diperlukan analisis yang dibutuhkan dari berbagai ilmu yang terdiri dari: Analisis sosial, analisis historis, analisis kultural dan analisis personal. ${ }^{\text {xviii }}$

Dengan demikian, bagi Nuhamara[2004: 333], tujuan dari analisa sosial adalah:

Untuk memahami berbagai sistem dominasi dalam masyarakat serta ideologiyang mendasarinya, untuk kemudian melakukan kritik ideologi. Inilah fungsi kenabian gereja dalam mengembangkan teologinya. Kritik ini bisa berarti kritik sosial tetapi sekaligus juga kritik agamawi, sebab ideologi yang peyoratif bisa berasal dari berbagai sistem kemasyarakatan tetapi juga dari institusi agamawi yakni teologinya. Jadi dengan berdialog dengan teori kritis, gereja diharapkan dapat melakukan kritik sosial dan agamawi sekaligus. Lebih khusus lagi gereja dimampukan melakukan kritik ideologi bahkan kritik diri sendiri yakni kritik terhadap teologi yang distorsif, yang menyebabkan manusia teralienasi bukan saja dari diri sendiri dan sesama tetapi juga dari alam ciptaan Tuhan oleh nafsu menguasai dan mendominasi baik sesama maupun alam ciptaan Tuhan. 
Selanjutnya, bila mengacu pada pengertian ideologi sebagaimana yang dikemukakan oleh Raymond Geuss ${ }^{\text {xix }}$, maka sesungguhnya teologi Gereja pun dapat dikategorisasikan sebagai suatu ideologi, khususnya dalam hal ini kategori ideologi deskriptif dan peyoratif. Artinya, Teologi sebagai sebuah ideologi dalam hal ini, telah mengisyaratkan adanya suatu paradigma yang mewarnai, melegitimasi [dan bahkan mendominasi] sikap umat maupun para pelayan / pemimpin gereja di kepulauan Kei. Kecenderungan Teologi [ideologi] yang ada, telah ikut mempengaruhi gereja baik terhadap praktek-praktek internal gerejawi maupun dalam hubungan eksternalnya dengan umatnya. Sehubungan dengan itu, maka tentunya teori kritik yang mengartikulasikan dan sekaligus memberikan konstribusi terhadap kritik-ideologi [ideologi kritik], menjadi semacam tools yang dapat membantu kita dalam mencari pertautan antara teori [gagasan, konsep, ide, doktrin, teologi, dan sebagainya] dengan praxis hidup manusia, beserta pelbagai wujudnya yang membias seperti: alienasi, reifikasi, dominasi, kekerasan dan ketidakadilan sosial. $^{\mathrm{xx}}$

Dalam konteks kehidupan bergereja dan bermasyarakat di kepulauan Kei, sistem kasta ini tetap dipertahankan dan merupakan bagian dari identitas kehidupan masyarakat di kepulauan Kei. Dalam realitas yang terjadi, terus saja ada diskriminasi-diskriminasi sosial di tengah-tengah kehidupan bermasyarakat dan bergereja. Misalnya: Tempat-tempat yang berbeda-beda di dalam Gereja, makam yang berbeda-beda di beberapa desa, pengingkaran partisipasi yang adil pada tingkat-tingkat kewenangan dan penolakan akses yang sama pada sumbersumber daya umum. Dengan demikian, kasta rendah [iri-iri] yang telah menjadi Kristen tidak bisa membebaskan diri mereka dari tatanan sosial budaya mereka, yang terungkap dalam bentuk kasta. Sebab bagi kasta rendah [iri-iri] tidak bisa melepaskan diri dari penindasan diskriminasi sosial yang ada. Hal ini, menunjukkan bahwa sistem kasta adalah pertama-tama struktur sosial-budaya, bukan struktur keagamaan.

Dengan demikian, kehadiran Gereja ditengah budaya tersebut seakan-akan tidak berpengaruh. Walaupun seringkali terdengar khotbah oleh Pendeta yang terambil dalam surat Galatia 3:2 yang menyatakan bahwa: "Dalam Kristus yang 
bangkit tidak ada orang Yahudi atau Yunani, tidak ada laki-laki atau perempuan, tidak ada budak atau orang merdeka". Namun maknayang terkandung dalam teks ini untuk direfleksikan oleh setiap orang adalah kesederajatan antara sesama manusia, seakan-akan tidak ditanggapi secara serius oleh jemaat yang hadir, khususnya mereka yang berasal dari kelas atas [mel-mel] dan kelas menengah [ren-ren].

Tujuan dari pembebasan adalah perubahan sosial-budaya. Pertanyaan yang perlu direfleksikan adalah: Bagaimana tugas dan tanggung jawab gereja dalam mengkritisi budaya kasta dimaksud? Seakan-akan kehadirangereja di kepulauan Kei dalam melihat realitas budaya yang terjadi, adalahseakan-akan toleran terhadap sistem kasta tersebut? Lalu, bagaimana dengan kehidupan segelintir orang yang terus didiskriminasi akibat budaya yang dianut?

Baum dalam buku, Religion and Alienation menjelaskan tentang apa itu teologi kritis? Dan bagaimana tugas dan tanggung jawab gereja dalam menyingkapi realita yang terjadi. Menurut Baum:

Teologi kritis adalah "aplikasi/ penerapan kritis dari berbagai teori tentang alienasi terhadap pemahaman iman dari gereja Kristen. Belajar dari teologi-teologi sosial khususnya yang menjelaskan tentang bagaimana manusia terasing [teralienasi] dan juga berbagai kritik agamawi, maka para teolog ini dapat memahami kecenderungan-kecenderungan yang ideologis dan pathogenis dalam tradisi agamawi mereka sendiri dan juga lebih luas dalam masyarakat."xxi

Dengan demikian, tugas dan tanggung jawab gereja adalah bukan saja mengajarkan tentang iman umatnya, namun juga melihat konsekuensi struktural dari praktek agama, untuk mengevaluasinya dipandang dari sudut pengajaran gereja berdasarkan norma, untuk memungkinkan gereja mengatur kembali kehadiran sosialnya sehingga konsekuensi sosialnya mendekati pernyataan imannya. Karena sehubungan dengan Injil Kristen tidaklah hanya pengajaran gereja dan mengambil keuntungan sejarah manusia. Teologi kritis memungkinkan gereja untuk mengasumsikan tanggung jawab mengenai agama untuk kenyataan sosialnya. Dalam pengertian ini, kemudian, teologi kritis adalah "cerminan atas praxis. ${ }^{x x i i}$ 
Oleh sebab itu, bagi Habermasxiii paradigma komunikasi yang ditawarkannya merupakan paradigma yang mampu membantu manusia untuk menembusi kendalakendala problematikanya dalam interaksinya dengan siapapun, termasuk dengan dirinya sendiri melalui proses refleksi diri. Dengan demikian,gereja sebagai "agen komunikator" [baca: saksi] berita keselamatan Allah bagi dunia, terpanggil untuk lebih mengkomunikasikan suara kenabiannya melalui diskursus-diskursus yang dapat membebaskan dirinya maupun sesamanya dari pelbagai belenggu ketidakadilan. Oleh karena itu, salah salah satu prasyarat yang dapat membantu gereja dalam hal melakukan otokritik-nya[refleksi-diri], yakni kesediaan dan keterbukaannya untuk melakukan dekonstruksi terhadap teologinya sendiri.

Memang benar, bahwa kasta bawah [iri-iri] cenderung menerima nasib mereka sebagaimana adanya, namun adapula pemberontakan, usaha untuk membebaskan diri dari nasib ini, meskipun hasil dari usaha-usaha ini dapat membawa mereka pada suatu pemenuhan pengharapan mereka yang tidak didugaduga. Dengan kata lain, di tengah-tengah situasi tanpa harapan, masih ada secerca sinar harapan. ${ }^{\text {xiv }}$

\section{G KESIMPULAN}

Berdasarkan pembahasan yang telah di kemukakan di atas, maka pelapisan sosial dalam masyarakat pada dasarnya merupakan suatu cara hidup dan gejala universal dari sistem sosial dalam setiap masyarakat. Di kepulauan Kei kasta telah menjadi lahan yang subur bagi bertumbuhnya benih sistem pelapisan masyarakat yang didasarkan pada fungsi, prestise, keturunan, kedudukan sosial dan ekonomi dalam masyarakat. Pelapisan sosial ini bersifat tertutup.

Namun, dalam perkembangan ilmu dan teknologi yang semakin pesat ini dituntut sebuah transformasi dalam kehidupan berbudaya. Karena budaya itu sendiri tidak bersifat statis namun dinamis. Oleh sebab itu, gereja dan pemerintah setempat harus berperan aktif dalam melihat persoalan-persoalan yang terjadi di tengah-tengah masyarakat. Agar jangan muncul pemahaman bahwa: struktur, sistem dan organisasi sosial masyarakat kepulauan Kei sangat ditentukan oleh kasta, baik dalam pengertian berdasarkan fungsi, keturunan maupun 
prestasi.Dengan demikian, yang muncul dalam kehidupan bergereja dan berbangsa adalah konsep "duduk sama rendah, berdiri sama tinggi”. Sehingga, tidak terjadi stratifikasi dimana ada sekelompok orang yang menganggap dirinya superior dan ada yang mengganggap dirinya inferior. Yang ada, dalam kehidupan bersama adalah melihat manusia sebagai sesama yang patut dihargai dan dihormati.

\section{Endnotes:}

\footnotetext{
${ }^{\mathrm{i}}$ Max Weber melengkapi pandangan Karl Marx, dalam Karel J. Veeger, Pengantar Sosiologi: Buku Panduan Mahasiswa, (Jakarta: Gramedia, 1993), h. 71. MenurutKarl Marx walaupun faktor ekonomi yang berperan besar dalam pembentukan kelas, masih ada faktor-faktor lain juga, seperti tingkat pendidikan, pembagian kekuasaan dan wewenang dan prestasi, yang mendasari suatu masyarakat yang berlapis-lapis.

${ }^{i i}$ Menurut sejarah masyarakat setempat sejak abad ke - XV dan XVI terjadi migrasi penduduk ke Kepulauan Kei salah satunya yakni kedatangan leluhur mereka dari Bali sangat berpengaruh dalam sistem adat dan terbentuknya hukum lokal yang disebut sebagai Hukum Larvul Ngabal, secara harfiah $[\mathrm{Lar}=$ darah, Vul = Merah; Nga = Tombak, Bal = Bali $]$. Baca: J. P Rahail, Larwul Ngabal Hukum Adat Kei, Jakarta: Yayasan Sejati, 1993. Selain itu pula pengaruhBali dalam budaya Kei terlihat dari warga masyarakat Kei yang umurnya sekitar 60an tahun ke atas masih memiliki nama Hindu sebelum menganut Agama: Islam dan Kristen.

iii Di Bali, penggolongan masyarakat berdasarkan tingkatan kasta di kenal dengan istilah catur warna, catur janma [jatma] dan catur wangsa dan dalam prakteknya masyarakat di bagi dalam empat golongan kasta yakni: Brahmana, Kesatria, Wesia [Wesya] dan Sudra, Baca. Anak Agung Gde Putra Agung, Perubahan Sosial dan Pertentangan kasta di Bali Utara, (Yogyakarta: Yayasan untuk Indonesia, 2001).

"Webster"s New International Dictionary of the English Language, (Springsfield: G \& C. Marriam Company, Publisher, 1951), hlm. 418.. Istilah ini digunakan di India karena negara ini juga menganut sistem kasta yang terdiri dari: Kshatriya, Brahmana, Vaishya dan Sudra. Baca. David G. Mandelbaum, Society in India [Volume Two: Change and Continuity], (Los Angeles: University Of California Press, 1970), hlm. 445-461.

${ }^{v}$ Dahrendorf dalam Aagn Ari Dwipayana, Kelas dan Kasta: Pergulatan Kelas Menengah di Bali, (Yogyakarta: Lapera Pustaka Utama, 2001), hlm. 27

${ }^{\mathrm{vi}}$ Lewis A. Cooser, Master of Sociological Thought: Ideas in Historical and Social Context, $2^{\text {nd }}$ Ed, (San Diego: Harcourt Brace Javanovich Publisher, 1971), hlm. 80 - 82.

vii Baca: Gregory Baum, Religion and Alienation: A Theological Reading Of Sociology, (New York: Paulist Press, 1975); Gregory Baum, Critical Theology, (Kansas City: Sheed \& Ward, 1923).

viii Cooser Op. cit, hlm. 228-230; Anthony Giddens danDavid Held, Kelompok, Kekuasaan dan Konflik, (Jakarta: Rajawali, 1987), hlm.29.

${ }^{\text {ix }}$ Sumber: DataStatistikMaluku Tenggara tahun 2003.

x Ohoitimur Yohanis, Beberapa Sikap Hidup Orang Kei: Antara Ketahanan Diri dan Proses Perubahan. Suatu Studi Antropologi Budaya Pastoral, (Tesis: Manado: Sekolah Tinggi Seminari Pinelang, 1983), hlm. 121.
} 
xi "Penduduk asli"yang dimaksudkan di sini adalah para migran yang pertama kali tiba dan menetap di Kei.

${ }^{x i i}$ Mengenai kelebihan yang dimiliki oleh para pendatangsebagai Mel-mel dan penduduk "asli"sebagai Ren-ren juga diakui olehvan Wouden, bahwa Ren kelompok yang lebih tua, tetapi juga yang bodoh, yang harus mengakui keunggulan Mel.Lihat. F. A. E. van Wouden, Klen, Mitos dan Kekuasaan. Struktur Sosial Indoensia Bagian Timur, (Jakarta: P. T. Temprint,1985), hlm.136.

xiii Ch. Labetubun, Hukum Laar In Turak Ngabal In Adung, [makalah tak diterbitkan], (Desa Laar I Tel, Kei Kecil Maluku Tenggara, 2003), hlm. 80-84.

${ }^{\text {xiv }}$ Kasta Iri-iri ini merupakan kelas bawah, mereka ditebus oleh kasta mel-mel maupun kasta renren sewaktu diberikan hukuman mati terhadap kesalahan yang mereka perbuat, sehingga seluruh hidup mereka ditanggung oleh pihak mel-mel maupun ren-ren, mereka diberikan kepercayaan untuk menjaga dan mengolah dusun dll. Sehingga dalam satu kampung pada satu marga terdapat tiga golongan kasta.

${ }^{x v}$ Kasta mel-mel dan ren-ren merupakan bagaikan simbiosis mutualisme, dimana gambarannya Mel menampati posisi laut [bekerja sebagai seorang nelayan] sedangkan kasta Ren menempati bagian gunung [Sebagai seorang petani] dan yang menjadi penghubung antara keduanya yakni kasta iri-iri dalam bentuk tukar menukar barang [barter]. Lih: Luis Th. Ubra, Hamaren. Studi Antroplogi Terhadap Sistem Tolong Menolong Di Kalangan Masyarakat Kepulauan Kei, Maluku Tenggara, Tesis, (Salatiga: UKSW, Februari 2005), hlm. 96, 110.

${ }^{x v i}$ Konsep yang sama dianut pula oleh warga Bali yang menganut sistem kasta, baca: Anak Agung Gde Agung, ibid. h. 41-42.

xvii Dalam pengamatan penulis, pucuk kepemimpinan baik pada instansi-instansi pemerintah maupun dalam gereja di kepulauan Kei,seringkali dipegang oleh orang-orang yang berasal dari kasta atas [mel-mel]. Beberapa orang Kasta bawah [iri-iri] yang berhasil dalam kerja dan lain-lain lebih cenderung untuk tetap tinggal di luar daerah kepulauan kei. Misalnya: Irian Jaya. dll.

xviii Untukuraian selengkapnya tentang analisis tersebut, baca:J. B. Banawiratma, et.al, Aspek-aspek Teologi Sosial, (Yogyakarta: Kanisius, 1990), hlm. 11-12; J. B. Banawiratma, et.al, Berteologi Sosial Lintas Ilmu: Kemiskinan Sebagai Tantangan Hidup Beriman, (Yogyakarta: 1993), hlm. 2330 .

${ }^{\text {xix }}$ Dalam bukunya "THE IDEA OF A CRITICAL THEORY - Habermas \& Frankfurt School" (London: Cambridge University Press, 1993), hal.5-22, Geuss mengemukakan 3 pengertian tentang ideologi, yakni: [a] ideologi dalam arti murni deskriptif, yang menunjuk kepada elemen diskursif seperti kepercayaan, konsep-konsep, dan elemen non-diskursif seperti ritual, sikap dan bentuk kegiatan artistik dan lainnya, yang dianut oleh suatu kelompok masyarakat. Dimana Agama/ Teologi tergolong pada elemen diskursif; [b] ideologi dalam arti peyoratif, yang mengisyaratkan adanya delusi atau kesadaran palsu yang cenderung melahirkan kepercayaan yang mendistorsikan realitas. Kesadaran palsu tersebut difungsionalisasikan dalam rangka mendukung, menstabilkan, membenarkan institusi dan praktek sosial tertentu. Termasuk praktek-praktek sosial yang mengeksploitasikan hubungan dan memperkokoh suatu hegemoni. Ideologi yang sedemikian cenderung pula untuk menghalangi perkembangan manusia secara penuh. Bahkan yang memprihatinkan adalah fungsinya yang cenderung menutupi atau menopengi kontradiksikontradiksi sosial sebagai realitas yang sebetulnya harus mendapat perhatian untuk diperbaiki. Ideologi peyoratif inipun dapatlah dimengerti dari aspek genetika-historisnya; [c] ideologi dalam pengertian positip, yang memungkinkan anggota kelompok memenuhi kebutuhan dan kepentingannya yang paling baik, entah yang bersifat material maupun non-material. Ideologi sedemikian perlu dikonstruksikan.

${ }^{\mathrm{xx}}$ Fransisco Budi Hardiman, Kritik Ideologi, (Yogyakarta: Kanisius, 1990), hlm. 5.

${ }^{x x i}$ Baum, Religion and Alienation..... hlm. 194.

xxii Baum, ibid, hlm. $194-195$.

xxiii Menurut Habermas, sebagai makhluk yang berbicara, maka ia mengintrodusir sebuah masyarakat komunikatif yang mampu melakukan kritik bukan melalui revolusi dengan jalan kekerasan, melainkan melalui argumentasi Fransisco, Budi Hardiman, Menuju Masyarakat Komunikatif - Ilmu, Masyarakat, Politik \& Postmodernisme menurutJurgen Habermas, (Yogyakarta: Kanisius, 1993), hlm. xxii. 
${ }^{x x i v}$ Baca: A. A. Yewangoe, Theologia Crucis Di Asia: Pandangan-Pandangan Orang Kristen Asia Mengenai Penderitaan Dalam Kemiskinan Dan Keberagamaan Di Asia, (Jakarta: BPK Gunung Mulia, 2004), hlm. 61.

\section{DAFTAR PUSTAKA}

\section{A Seri Buku Terpublikasi}

Abercrombie Nikolas, 1980.Class, Structure and Knowledge: Problems in the Sociology of Knowledge, New York: New York University Press.

Amaladoss Michael,. 2001.Teologi Pembebasan Asia, Yogyakarta: Pustaka Pelajar \& Insisit Press,

Baum Gregory, 1975. Religion and Alienation: A Theological Reading Of Sociology, New York:Paulist Press.

-----------, 1923. Critical Theology, Kansas City: Sheed \& Ward.

Banawiratma, J. B,et.al,1990. Aspek-aspek Teologi Sosial, Yogyakarta: Kanisius. , et.al, 1993. Berteologi Sosial Lintas Ilmu: Kemiskinan Sebagai Tantangan Hidup Beriman, Yogyakarta.

Burke Peter, 2003. Sejarah dan Teori Sosial, Jakarta: Yayasan Obor Indonesia.

Cooser Lewis A, 1971. Master of Sociological Thought: Ideas in Historical and Social Context, $2^{\text {nd }}$ Ed, San Diego: Harcourt Brace Javanovich Publisher,

Dahrendorf dalam Aagn Ari Dwipayana, 2001. Kelas dan Kasta: Pergulatan Kelas Menengah di Bali, Yogyakarta: Lapera Pustaka Utama.

Geuss Raymond, 1993. The Idea Of A Critical Theory - Habermas \& Frankfurt School, Cambridge. London:University Press.

Giddens AnthonydanDavid Held,1987. Kelompok, Kekuasaan dan Konflik, Jakarta: Rajawali.

Hardiman Budi Fransisco, 1990. Kritik Ideologi, Yogyakarta: Kanisius.

------------, 1993. Menuju Masyarakat Komunikatif - Ilmu, Masyarakat, Politik \& Postmodernisme menurut Jurgen Habermas, Yogyakarta: Kanisius.

Mackinnon Susan, From A Shattered Sun: 1991. Hierarchy, Gender, and Alliance in the Tanimbar Islands, The University of Wisconsin Press.

Mandelbaum David G, 1970. Society in India [Volume Two: Change and Continuity], Los Angeles: University Of California Press.

Rahail, J. P, 1993.Larwul Ngabal Hukum Adat Kei,Jakarta: Yayasan Sejati. 
Soekanto Soerjono,1990. Sosiologi Suatu Pengantar, Jakarta: PT Raja Grafindo Persada.

Siahaan M Hotman, 1986. Pengantar Ke Arah Sejarah dan Teori Sosiologi, Jakarta:Erlangga.

Veeger J Karel, 1993. Pengantar Sosiologi: Buku Panduan Mahasiswa, Jakarta: Gramedia.

Weber Max, 2000. Etika Protestan dan Semangat Kapitalisme, Surabaya: Pustaka Promethea.

1951. Webster"s New International Dictionary of the English Language, Springsfield: $19 \mathrm{G} \& \mathrm{C}$ Marriam Company Publisher.

Wouden van F. A. E, 1985. Klen, Mitos dan Kekuasaan. Struktur Sosial Indoensia Bagian Timur, Jakarta: PT. Temprint.

Yewangoe, A A, 2004. Theologia Crucis di Asia: Pandangan-Pandangan Orang Kristen Asia Mengenai Penderitaan Dalam Kemiskinan dan Keberagamaan Di Asia, Jakarta: BPK Gunung Mulia.

Hardiman Budi Fransisco, 1993. Menuju Masyarakat Komunikatif-Ilmu, Masyarakat, Politik \& Postmodernisme menurutJurgen Habermas, Yogyakarta: Kanisius.

\section{B. Seri Tesis, Jurnal, Makalah}

Labetubun Ch, 2003, Hukum Laar In Turak Ngabal In Adung, [makalah tak diterbitkan], Desa Laar I Tel, Kei Kecil Maluku Tenggara.

Nuhamara Daniel, Kritik, Utopia dan Praksis Pembebasan: Unsur-unsur dalam Berteologi Sosial Transformatif dalam Kritis: Jurnal Studi Pembangunan Interdisiplin, Vol. XVI, No. 3, Desember 2004

Ohoitimur Yohanis, 1983. Beberapa Sikap Hidup Orang Kei: Antara Ketahanan Diri dan Proses Perubahan. Suatu Studi Antropologi Budaya Pastoral, Tesis: Manado: Sekolah Tinggi Seminari Pinelang.

Ubra Luis Th, Hamaren: Studi Antroplogi Terhadap Sistem Tolong Menolong Di Kalangan Masyarakat Kepulauan Kei, Maluku Tenggara, Tesis, Salatiga: UKSW, Februari 2005. 